\title{
Effect of planting pattern of forage sorghum on forage productivity and heifer performance during finishing phase
}

\author{
Efeito do padrão de plantio do sorgo forrageiro sobre a \\ produtividade de forragem e desempenho de \\ novilhas em terminação
}

\author{
Leonel da Silva Rodrigues ${ }^{1 *}$; Dari Celestino Alves Filho²; Ivan Luiz Brondani²; \\ Viviane Santos da Silva ${ }^{3}$; Perla Cordeiro de Paula ${ }^{3}$; Sander Martinho Adams ${ }^{4}$; \\ Patrícia Machado Martini ${ }^{4}$; Gilmar dos Santos Cardoso ${ }^{1}$
}

\begin{abstract}
This study aimed to assess the effect of sorghum planting patterns on forage response and performance of beef heifers at finishing phase. The experimental period lasted 84 days; treatments consisted of the combination of two interrow spacings (22 and $44 \mathrm{~cm})$ and two sorghum-sowing rates $(12$ and $24 \mathrm{~kg}$ $\left.\mathrm{ha}^{-1}\right)$. Beef heifers, at finishing phase, with initial age of 15 months ( \pm 2.3 months $)$ and average body weight of $262 \mathrm{~kg}( \pm 37.95 \mathrm{~kg})$, continuously grazed forage. The experimental design was completely randomized in a $2 \times 2$ factorial scheme with three repetitions per area. The different planting patterns did not affect $(\mathrm{P}>0.05)$ dry matter production $\left(5,447.78 \mathrm{~kg} \mathrm{DM} \mathrm{ha}^{-1}\right)$ and accumulation rate $(58.47 \mathrm{~kg}$ $\left.\mathrm{DM} \mathrm{ha}^{-1} \mathrm{day}^{-1}\right)$. Forage accumulation rate, leaf mass, forage mass, leaf supply and forage supply were influenced $(\mathrm{P}<0.05)$ by time. Similar behavior was observed for stocking rate, weight gain per area unit and daily weight gain, with values of $1,172.32 \mathrm{~kg}$ of liveweight ha- ${ }^{-1}, 312.31 \mathrm{~kg} \mathrm{ha}^{-1} ; 0.891 \mathrm{~kg} \mathrm{day}^{-1}$, respectively. Animal performance had no effect $(\mathrm{P}>0.05)$ from planting patterns, with nearly $4.04 \mathrm{~mm}$ of subcutaneous fat thickness and final weight of $330.36 \mathrm{~kg}$. Animal body development showed no significant differences $(\mathrm{P}>0.05)$, with values for length, heart girth and hip height of 132.01, 163.75 and $126.75 \mathrm{~cm}$, respectively. The weight to average height ratio between planting patterns was $2.67 \mathrm{~kg}$ $\mathrm{cm}^{-1}$.
\end{abstract}

Key words: Stocking rate. Interrow spacing. Body weight gain. Sorghum bicolor. Sowing rate.

\section{Resumo}

Objetivou-se avaliar os efeitos de diferentes padrões de plantio do sorgo forrageiro na resposta forrageira e no desempenho produtivo de novilhas de corte em terminação. O período experimental teve duração 84 dias. Os tratamentos consistiram na combinação de dois espaçamentos entrelinhas (22 e $44 \mathrm{~cm})$ e duas taxas de semeadura do sorgo (12 e $\left.24 \mathrm{~kg} \mathrm{ha}^{-1}\right)$. Para o pastejo das forragens produzidas, foram utilizadas novilhas de corte, em fase de terminação, com idade média inicial de 15 meses $( \pm 2,3$ meses) e peso corporal médio de $262 \mathrm{~kg}( \pm 37,95 \mathrm{~kg})$. O método de pastoreio foi contínuo. O delineamento experimental utilizado foi o inteiramente casualizado com três repetições por área, em esquema fatorial 2

\footnotetext{
${ }^{1}$ Discentes, Curso de Doutorado, Programa de Pós-Graduação em Zootecnia, Universidade Federal de Santa Maria, UFSM, Santa Maria, RS, Brasil. E-mail: rodrigues leonel@hotmail.com; gilmarcardoso86@gmail.com

2 Profs. Drs., Departamento de Zootecnia, UFSM, Santa Maria, RS, Brasil. E-mail: darialvesfilho@hotmail.com; ivanbrondani@ gmail.com

3 Zootecnistas, Drs., UFSM, Santa Maria, RS, Brasil. E-mail: perla.zoot@gmail.com; stsvivi@gmail.com

${ }^{4}$ Zootecnistas, UFSM, Santa Maria, RS, Brasil. E-mail: sander.adams@homail.com; patriciammartini@hotmail.com

* Author for correspondence
} 
$x$ 2. Os diferentes padrões de plantio não influenciaram $(P>0,05)$ na produção de matéria seca $(5447,78$ $\mathrm{kg}$ de MS ha $\left.{ }^{-1}\right)$ e na taxa de acúmulo de matéria seca $\left(58,47 \mathrm{~kg}\right.$ de $\left.\mathrm{MS} \mathrm{ha}^{-1} \mathrm{dia}^{-1}\right)$. As variáveis taxa de acúmulo de forragem, massa de lâminas foliares, massa de forragem, oferta de lâminas foliares e oferta de forragem foram influenciados $(\mathrm{P}<0,05)$ pelo avanço do período de utilização. Comportamentos similares foram observados para as variáveis: carga animal, ganho de peso por área e ganho de peso diário, com valores de $1172,32 \mathrm{~kg}$ de peso vivo ha ${ }^{-1} ; 312,31 \mathrm{~kg} \mathrm{ha}^{-1} ; 0,891 \mathrm{~kg} \mathrm{dia}^{-1}$, respectivamente. $\mathrm{O}$ desempenho animal não foi influenciado $(\mathrm{P}>0,05)$ pelos padrões de plantio do sorgo, obtendo-se, em média, 4,04 $\mathrm{mm}$ de espessura de gordura subcutânea e peso final de $330,36 \mathrm{~kg}$. O desenvolvimento corporal dos animais não apresentou diferenças significativas $(\mathrm{P}>0,05)$, com valores para comprimento, perímetro torácico, e altura de garupa de 132,$01 ; 163,75 ; 126,75 \mathrm{~cm}$, respectivamente. A relação peso: altura média entre os padrões de plantio foi de $2,67 \mathrm{~kg} \mathrm{~cm}^{-1}$.

Palavras-chave: Carga animal. Espaçamento entrelinhas. Ganho de peso corporal. Sorghum bicolor. Taxa de semeadura.

\section{Introduction}

The intensification of beef cattle production systems involves the maximization of the use of forage resources using forage crops that have high productivity, good support capability and maximization of weight gains per area unit. The forage sorghum (Sorghum bicolor L. Moench) is a summer annual grass that adds quality to the feeding system and the adoption of pasture management strategies can optimize animal performance and forage production.

In forage sorghum pastures are reported weight gain of $1.121 \mathrm{~kg} \mathrm{day}^{-1}$ (RESTLE et al., 2002) and $0.608 \mathrm{~kg} \mathrm{day}^{-1}$ (NEUMANN et al., 2005) during steer rearing and $0.833 \mathrm{~kg} \mathrm{day}^{-1}$ for steers at finishing phase (DEVINCENZI et al., 2012). These authors also reported weight gain per area unit ranging from 3.16 to $5.82 \mathrm{~kg}$ day $\mathrm{ha}^{-1}$.

Changing planting patterns of crops, which includes the spatial distribution and the area occupied by the plant, is one of the ways to get increased productivity and quality of forage because of a greater efficiency in exploring factors such as water, light and nutrients. According Brachtvogel et al. (2009), the environmental exploration optimization is necessary to maximize crop yields. Thus, the decreased interrow spacing and increased seed density per area can increase the exploitation efficiency of environmental factors, reflecting in forage production and animal performance.
According to Argenta et al. (2001), different arrangements of plants can be obtained through changes in plant density, interrow spacing and distribution of plants in the row. The use of reduced spacing increases the initial crop growth rates due to a better interception of solar radiation and its higher utilization efficiency, resulting in higher productivities (BULLOCK et al., 1988). However, in more advanced physiological stages it may negatively affect the tillering because of an increased competition for biotic and abiotic factors (MAGALHÃES et al., 2011).

There are different recommendations for interrow spacing (17 to $70 \mathrm{~cm}$ ) and population density $\left(150,000\right.$ to 600,000 plants $\left.\mathrm{ha}^{-1}\right)$ for the cultivation of forage sorghum (CHIELLE et al., 2001; CARNEIRO et al., 2004; GONTIJO NETO et al., 2006). The search for planting patterns in which crops reach high yield for both biomass production and grain is subject of many investigations (BRACHTVOGEL et al., 2009; MARSALIS et al., 2010; NEUMANN et al., 2008). However, the study of planting patterns in forage plants is still scarce in the literature. In this context, the aim of this study was to assess the effects of reduced planting patterns on productive pasture parameters and heifer performance at finishing phase. 


\section{Materials and Methods}

The protocol of this study was approved by the Ethics Committee on Animal Use of the Federal University of Santa Maria (UFSM) under the number $128 / 2014$.

The experiment was conducted at the Federal University of Santa Maria, located in the central depression of Rio Grande do Sul, in the period from November 15, 2013 to April 11, 2014. The regional climate is $\mathrm{Cfa}$ (humid subtropical) type, as the classification of Köppen (ALVARES et al., 2013). The soil of the experimental area belongs to the mapping unit São Pedro and it is classified as an arenic dystrophic Red Argisol (Hapludalf) (STRECK et al., 2008). The soil analysis showed the following results: $\mathrm{pH}$ in $\mathrm{H}_{2} \mathrm{O}=4.67 ; \mathrm{P}=13.20$ $\mathrm{mg} \mathrm{dm}{ }^{-3} ; \mathrm{K}=81.33 \mathrm{mg} \mathrm{dm}{ }^{-3} ; \mathrm{Ca}^{+2}=6.17 \mathrm{cmol}_{\mathrm{c}}$ $\mathrm{dm}^{-3} ; \mathrm{Mg}^{+2}=2.87 \mathrm{cmol}_{\mathrm{c}} \mathrm{dm}^{-3} ; \mathrm{Al}(\%)=16.27 ; \mathrm{BS}$ $(\%)=48.73 ; \mathrm{CEC}_{\mathrm{pH} 7}=19.00 \mathrm{cmol}_{\mathrm{c}} \mathrm{dm}^{-3} ; \mathrm{OM}(\%)$ $=2.33$.
The experimental area used corresponded to 16.3 ha, being 11.7 ha divided into 12 paddocks with variable area where the testing animals were managed, and 4.6 ha where remained the regulator animals. The pasture implementation occurred on November 15, 2013 using a seeder in no-till system on straw of oat pasture (Avena strigosa) and ryegrass (Lolium multiflorum L.). A pre-planting desiccation was carried out with the application of $3.0 \mathrm{~L} \mathrm{ha}^{-1}$ of glyphosate. It was applied $150 \mathrm{~kg}$ $\mathrm{ha}^{-1}$ of the fertilizer N-P-K with formulation 5-2020. An amount of $45 \mathrm{~kg} \mathrm{ha}^{-1}$ of urea was applied in topdressing, being divided into two applications. The seeder was adjusted according to the density and spacing used in each treatment; the sowing depth was of 5 to $7 \mathrm{~cm}$ and the soil had adequate moisture for seed germination.

Table 1 shows the average monthly values of insolation, precipitation and temperature observed during the experimental period and their historical averages (1984-2014) to the city of Santa Maria, RS, Brazil.

Table 1. Average monthly insolation, precipitation and temperatures from November 2013 to April 2014 and historical averages (1984-2014) to the city of Santa Maria, RS, Brazil.

\begin{tabular}{lrrrrrr}
\hline \multicolumn{1}{c}{ Historical series } & Nov. & Dec. & Jan. & Feb. & Mar. & Apr. \\
\hline Insolation (hours) & 223.75 & 250.41 & 248.69 & 201.5 & 212.11 & 178.74 \\
Precipitation (mm) & 116.9 & 144.73 & 155.97 & 128.58 & 124.49 & 155.61 \\
Maximum temperature $\left({ }^{\circ} \mathrm{C}\right)$ & 27.85 & 30.39 & 31.02 & 30.11 & 29.06 & 25.58 \\
Minimum temperature $\left({ }^{\circ} \mathrm{C}\right)$ & 17.99 & 18.49 & 17.77 & 19.72 & 14.35 & 12.52 \\
Experimental period -2013 to 2014 & Nov. & Dec. & Jan. & Feb. & Mar. & Apr. \\
Insolation (hours) & 229.20 & 286.30 & 229.30 & 218.90 & 212.60 & 186.20 \\
Precipitation (mm) & 294.50 & 92.80 & 132.3 & 109 & 226.9 & 105.1 \\
Maximum temperature $\left({ }^{\circ} \mathrm{C}\right)$ & 28.73 & 32.12 & 32.62 & 32.13 & 28.4 & 25.8 \\
Minimum temperature $\left({ }^{\circ} \mathrm{C}\right)$ & 17.52 & 19.70 & 21.23 & 20.64 & 17.2 & 15.7 \\
\hline
\end{tabular}

Source: Instituto Nacional de Meteorologia, Station of Santa Maria, RS, Brazil (2015).

The treatments were the combination of two spacings (22 or $44 \mathrm{~cm}$ interrows) and two seed densities ( 12 or $24 \mathrm{~kg} \mathrm{ha}^{-1}$ ), totaling four treatments: S22D24, spacing of $22 \mathrm{~cm}$ interrow and seed density of $24 \mathrm{~kg} \mathrm{ha}^{-1}$; S44D24, spacing of $44 \mathrm{~cm}$ interrow and seed density of $24 \mathrm{~kg} \mathrm{ha}^{-1}$; S22D12, spacing of $22 \mathrm{~cm}$ interrow and seed density of $12 \mathrm{~kg}$ $\mathrm{ha}^{-1}$; S44D12, spacing of $44 \mathrm{~cm}$ interrow and seed density of $12 \mathrm{~kg} \mathrm{ha}^{-1}$. These combinations resulted in the following densities: 66.36, 56.29, 40.91, and 25.91 plants $\mathrm{m}^{2}$ for the treatments S22D24, S44D24, S22D12 and S44D12, respectively. Each treatment consisted of three repetitions of area. 
The grazing method was continuous with variable stocking rate, as the methodology proposed by Moot and Lucas (1952). The forage mass of the pasture was controlled in order to maintain a forage supply of $9 \%$ ( $9 \mathrm{~kg}$ of DM per $100 \mathrm{~kg}$ of liveweightLW) considering the leaf mass of sorghum + forage mass of invasive species, as alexandergrass (Urochloa plantaginea) and hairy crabgrass (Digitaria sanguinalis). It was used 36 beef heifers from the crossbreeding between Charolais and Nellore, with average initial age and liveweight of 15 months ( \pm 2.3 months) and $262 \mathrm{~kg}( \pm 37.95$ $\mathrm{kg}$ ), respectively, remaining in each paddock three testing heifers and variable number of regulators. The animal adaptation period to the pasture facilities was of 15 days, followed by the experimental period (beginning on January 18, 2014), which lasted 84 days and was divided into three periods of 28 days, being the period 1 from January 1 to February 15, the period 2 from February 16 to March 15 and the period 3 from March 3 to April 4.

The animals received daily supplementation (at 11:00 h), which was balanced so that the offer of $1 \%$ of LW would provide gain of $1.100 \mathrm{~kg} \mathrm{day}^{-1}$ (NRC, 1996), and adjusted weekly as estimated daily weight gain. The levels of crude protein and total digestible nutrients of the supplement were 144.0 and $767.0 \mathrm{~g}$ $\mathrm{kg}^{-1}$ of DM, respectively, based on the nutritional requirements of the animals. All treatments received the same supplement, which was formulated from the ratio of $62.9 \%$ of oat grain, $35 \%$ of corn grain, $1 \%$ of urea and $1.1 \%$ of calcitic limestone.

The canopy height was determined by measuring the average folding of the canopy leaves using a graduated ruler, taking the measure at 50 points per paddock. The forage mass was determined by the double sampling technique (WILM et al., 1944) at the beginning of the grazing period and, subsequently, every 14 days. In each repetition, there were five cuts of $0.25 \mathrm{~m}^{2}$ each, close to soil, and 20 visual estimates. From each cut made in the repetition, a sample was taken for composing one composite sample for determining the content of dry matter (DM) of the pasture. The stocking rate for each period was calculated from the equation described by Alves et al. (2016): Stocking rate = $(\mathrm{Wt}+(\mathrm{Wr} \times \mathrm{D})) / \mathrm{NDP}$, where $\mathrm{Wt}$ is the average weight of the testing animals, Wr is the weight of the regulator animals, $\mathrm{D}$ is the number of days that the regulator animals remained in the pasture, and NDP is the number of days in the period.

The estimated dry matter daily accumulation rate of the pasture was carried out every 28 days using three grazing-exclusion cages per paddock, according to the methodology described by Klingman et al. (1943). After collecting the material from the grazing-exclusion cages, it was separated into forage sorghum blades and other species. The dry matter accumulation rate per period was estimated using the equation described by Campbell (1966): $\mathrm{AR}=(\mathrm{Ci}-\mathrm{Fg}(\mathrm{i}-1)) / \mathrm{n}$, where AR is the dry matter daily accumulation rate per ha, $\mathrm{Ci}$ is the average amount of dry matter per ha in the three cages in the assessment i, Fg is the average amount of dry matter per ha in the three assessment point $i-$ 1 , and $\mathrm{n}$ is the number of days in the period.

The total dry matter production (DMP) was calculated by the sum of productions of the periods (daily accumulation rate $\times$ number of days) plus the initial forage mass. From the values of the forage mass, accumulation rate of forage sorghum and invasive species, and stocking rate, it was determined the forage supply of sorghum leaf blade and invasive species, both in $\mathrm{kg}$ of DM per $100 \mathrm{~kg}$ of LW, using the equation described by Sollenberg et al. (2005): FA = (((MFi + MFf $) / 2) /$ number of days $)$ + DAR $) \times 100) / \mathrm{SR}$, where FA is the forage supply of the period, MFi is the initial forage mass of the period, MFf is the final forage mass of the period, DAR is the dry matter daily accumulation rate of the period, and SR is the stocking rate of the period.

The structural and botanical composition of the pasture was assessed in three representative areas in squares of $0.25 \mathrm{~m}^{2}$. The forage was cut and packaged in bags and later separated into leaf blade, stem + leaf sheath, dead material and invasive species. 
To determine the bromatological forage contents consumed by the animals, a grazing simulation was performed by observing the feeding behavior of the animals for 15 minutes. Two trained raters collected about $0.4 \mathrm{~kg}$ of forage material, as described by Euclides et al. (1992). The samples were predried in a forced air circulation oven at $55^{\circ} \mathrm{C}$ to constant weight, grinded in a Wiley mill in sieve with 1-mm cribble, and subsequently analyzed the contents of dry matter (DM), total nitrogen (N) and neutral detergent fiber (NDF). The contents of DM were determined by drying the forage material in an oven at $105^{\circ} \mathrm{C}$ to constant weight and the ashes by calcination in an oven, at $550{ }^{\circ} \mathrm{C}$, to constant weight. The total nitrogen content was determined by the Kjeldahl method (AOAC, 1995) and the NDF content as Van Soest et al. (1991).

The animal weight was obtained at the beginning and end of each period of the experiment, prior to a 12hour solid and liquid fasting. During the weighings, the body condition of the animals was assessed by assigning scores from 1 to 5 , where $1=$ very thin and $5=$ very fat, according to the methodology described by Lowman et al. (1973). The average daily gain (ADG) was obtained by dividing the weight gain in the period by the number of days of the period. The gain in body condition score (GBCS) was obtained by subtracting the final body condition score of the experimental period from the initial body condition score of the experimental period. The weight gain per area unit (WGA) was obtained from the daily weight gain per hectare multiplied by the number of days in the period.

At the beginning and end of the experimental period, it was performed the measurements of hip height, animal's body length and heart girth using a hipometer and graduated ruler; the animal was immobilized in a contention trunk and remained with the back line straight. For the hip height was considered the extension from the ilium to the ground and for the animal's length was considered the point of the scapula to the point of the ischium. The weight to height ratio was determined by dividing the animal weight by its height. The measurements of area of the muscle Longissimus dorsi and subcutaneous fat thickness were performed at the end of the experimental period by means of capturing images using the ultrasound ALOKA SSD 500 and their interpretation using the software BIOTRONIC-BioSoftToolbox ${ }^{\circledR}$.

The experimental design was completely randomized in a $2 \times 2$ factorial scheme (two interrow spacings and two seed densities) with three repetitions per area. The Shapiro-Wilk normality test was performed for all variables in order to observe the normal behavior of the residuals; when necessary, the variables that did not present normality were transformed.

The data were analyzed by the MIXED procedure (Statistical Analysis System, SAS Studio University Edition, version 3.5). The measures taken in each experimental period were considered repeated over time. It was analyzed the interaction effect between the interrow spacing and seed density; when no significant, the effects were considered independently. The correlation analysis was performed using the CORR procedure (Statistical Analysis System, SAS Studio University Edition, version 3.5). The differences between means were analyzed by the t test $(\mathrm{P}<0.05)$. The statistical model adopted was:

$$
\begin{gathered}
\text { Yijk }=\mu+\mathrm{S}+\mathrm{D}+(\mathrm{S} \times \mathrm{D})+\mathrm{Rk}(\mathrm{S} \times \mathrm{D})+\mathrm{Pj}+ \\
(\mathrm{Pj} \times \mathrm{S} \times \mathrm{D})+\text { eijk }
\end{gathered}
$$

where Yijk are the dependent variables, $\mu$ is the average of all observations, $S$ is the effect of spacing, $\mathrm{D}$ is the effect of density, $(\mathrm{S} \times \mathrm{D})$ is the interaction effect between spacing and density, $\mathrm{Rk}$ $(\mathrm{S} \times \mathrm{D})$ is the effect of the $\mathrm{k}$-th repetition within each treatment, $\mathrm{Pj}$ is the effect of the $\mathrm{j}$-th period, $(\mathrm{Pj} \times \mathrm{S} \times$ D) is the interaction effect between period, spacing and density, and eijk is the total experimental error. 


\section{Results and Discussion}

There was no interaction $(\mathrm{P}>0.05)$ between planting patterns $(\mathrm{S} \times \mathrm{D})$ and the assessment periods. Similarly, it was not observed interaction $(\mathrm{P}>0.05)$ between the interrow spacings (S), seed density (D) and the assessment periods.

Table 2 shows the results for the structural components and qualitative characteristics of the pasture. On average, the participation of leaves and other species accounted respectively for $11.57 \%$ and $18.20 \%$ of the total pasture components.
The general average contents of DM and CP presented values of 219.36 and $164.14 \mathrm{~g} \mathrm{~kg}^{-1}$ of $\mathrm{DM}$, respectively; the values of NDF and organic matter (OM) were of 707.64 and $919.7 \mathrm{~g} \mathrm{~kg}^{-1}$ of $\mathrm{DM}$, respectively. The equivalences of qualitative values of the forage collected by grazing simulation reflected in the similarity of the animal performance observed between planting patterns. The crude protein contribution of the pasture was higher than the requirements of beef heifers, which are of $126 \mathrm{~g}$ $\mathrm{kg}^{-1}$ of DM according to NRC (1996).

Table 2. Structural components and chemical composition of the forage obtained by grazing simulation.

\begin{tabular}{lrrrrrrrr}
\hline Interrow spacing, cm & \multicolumn{3}{c}{44} & \multicolumn{2}{c}{22} & \multirow{2}{*}{ SEM $^{2}$} & \multicolumn{3}{c}{$\mathrm{P}<\mathrm{F}^{1}$} \\
\cline { 2 - 4 } Density, $\mathrm{kg} \mathrm{ha}^{-1}$ & \multicolumn{1}{c}{12} & \multicolumn{1}{c}{12} & \multicolumn{1}{c}{24} & & $\mathrm{~S}$ & $\mathrm{D}$ & $\mathrm{S} \times \mathrm{D}$ \\
\hline $\mathrm{L}$ & 621.82 & 708.00 & 668.58 & 514.98 & 148.23 & 0.584 & 0.286 & 0.686 \\
$\mathrm{~S}$ & 2459.07 & 2288.89 & 3442.44 & 2038.44 & 649.09 & 0.527 & 0.410 & 0.416 \\
$\mathrm{DPM}$ & 1286.02 & 1371.26 & 1210.12 & 983.08 & 196.61 & 0.494 & 0.619 & 0.547 \\
$\mathrm{O}$ & 667.20 & 724.00 & 1421.75 & 1313.64 & 271.83 & 0.100 & 0.573 & 0.457 \\
$\mathrm{DM}$ & 217.69 & 231.86 & 218.19 & 209.69 & 13.33 & 0.547 & 0.809 & 0.376 \\
$\mathrm{OM}$ & 923.93 & 921.76 & 921.38 & 911.73 & 3.12 & 0.053 & 0.071 & 0.242 \\
$\mathrm{CP}$ & 166.55 & 164.39 & 163.23 & 162.39 & 4.91 & 0.827 & 0.875 & 0.584 \\
NDF & 703.48 & 709.50 & 710.07 & 707.52 & 4.82 & 0.635 & 0.721 & 0.380 \\
\hline
\end{tabular}

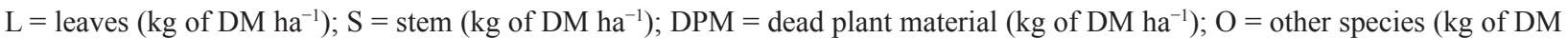
$\left.\mathrm{ha}^{-1}\right) ; \mathrm{DM}=$ dry matter $\left(\mathrm{g} \mathrm{kg}^{-1}\right.$ of $\left.\mathrm{DM}\right) ; \mathrm{OM}=$ organic matter $\left(\mathrm{g} \mathrm{kg}^{-1}\right.$ of DM $) ; \mathrm{CP}=$ crude protein $\left(\mathrm{g} \mathrm{kg}^{-1}\right.$ of DM); NDF = neutral detergent fiber $\left(\mathrm{g} \mathrm{kg}^{-1}\right.$ of DM).

${ }^{1}$ Effect of S: spacing; D: density; $\mathrm{S} \times \mathrm{D}$ : interaction between spacing and density.

${ }^{2} \mathrm{SEM}$ : standard error of the mean.

The qualitative characteristics of the forage apparently consumed by the animals were influenced by the assessment periods (Table 3). The DM content was higher in the period 1 (246.83 $\mathrm{g} \mathrm{kg}^{-1}$ of DM) when compared to the periods 2 (202.34 $\mathrm{g} \mathrm{kg}^{-1}$ of DM) and 3 (208.91 $\mathrm{g} \mathrm{kg}^{-1}$ of DM), which may be related to the increased participation of the alexandergrass (Urochloa plantaginea) and hairy crabgrass (Digitaria sanguinalis) at the beginning of the production cycle and lower dry matter content in the structural composition of the pasture in the periods $2(32.95 \%)$ and $3(22.36 \%)$. The highest crude protein content was found in the forage mass from the second assessment period (175.10 $\mathrm{g} \mathrm{kg}^{-1}$ of DM), reflecting in higher ADG $\left(1.117 \mathrm{~kg} \mathrm{day}^{-1}\right)$. Similarly, the lowest protein value, observed in the third period, resulted in lower ADG $(\mathrm{r}=0.65 ; \mathrm{P}<0.0001)$. 
Table 3. Structural components and chemical composition of the forage obtained by grazing simulation, expressed by assessment periods.

\begin{tabular}{|c|c|c|c|c|c|}
\hline & \multicolumn{3}{|c|}{ Period } & \multirow{2}{*}{$\mathrm{SEM}^{1}$} & \multirow{2}{*}{$\mathrm{P}<\mathrm{F}$} \\
\hline & 1 & 2 & 3 & & \\
\hline L & $1559.30^{\mathrm{a}}$ & $151.63^{b}$ & $174.10^{\mathrm{b}}$ & 135.84 & 0.0001 \\
\hline S & $3989.60^{\mathrm{a}}$ & $2131.67^{b}$ & $1550.37^{b}$ & 443.63 & 0.0008 \\
\hline DPM & $268.52^{\mathrm{c}}$ & $780.00^{\mathrm{b}}$ & $2589.33^{\mathrm{a}}$ & 173.45 & 0.0001 \\
\hline $\mathrm{O}$ & $3.47^{\mathrm{b}}$ & $1505.37^{\mathrm{a}}$ & $1242.63^{\mathrm{a}}$ & 204.71 & 0.0002 \\
\hline $\mathrm{DM}$ & $246.83^{a}$ & $202.34^{\mathrm{b}}$ & $208.91^{\mathrm{b}}$ & 9.95 & 0.012 \\
\hline $\mathrm{OM}$ & $927.03^{\mathrm{a}}$ & $918.79^{b}$ & $913.75^{\mathrm{b}}$ & 2.27 & 0.003 \\
\hline $\mathrm{CP}$ & $170.42^{\mathrm{b}}$ & $175.10^{\mathrm{a}}$ & $146.90^{\mathrm{c}}$ & 1.87 & 0.0001 \\
\hline $\mathrm{NDF}$ & $715.37^{\mathrm{a}}$ & $694.94^{\mathrm{b}}$ & $712.61^{\mathrm{a}}$ & 3.47 & 0.001 \\
\hline
\end{tabular}

$\mathrm{L}=$ leaves $\left(\mathrm{kg}_{\mathrm{g}}\right.$ of DM ha $\left.{ }^{-1}\right) ; \mathrm{S}=$ stem $\left(\mathrm{kg}\right.$ of DM ha $\left.{ }^{-1}\right) ; \mathrm{DPM}=$ dead plant material $\left(\mathrm{kg}\right.$ of DM ha $\left.{ }^{-1}\right) ; \mathrm{O}=$ other species $(\mathrm{kg}$ of DM $\left.\mathrm{ha}^{-1}\right) ; \mathrm{DM}=$ dry matter content $\left(\mathrm{g} \mathrm{kg}^{-1}\right.$ of DM); OM = organic matter content $\left(\mathrm{g} \mathrm{kg}^{-1}\right.$ of DM $) ; \mathrm{CP}=$ crude protein content $\left(\mathrm{g} \mathrm{kg}^{-1}\right.$ of $\mathrm{DM}) ; \mathrm{NDF}=$ neutral detergent fiber content $\left(\mathrm{g} \mathrm{kg}^{-1}\right.$ of $\left.\mathrm{DM}\right)$.

Means in the same row, followed by different letters, are statistically different from each other by the $t$ test $(\mathrm{P}<0.05)$.

${ }^{1} \mathrm{SEM}$ : standard error of the mean.

Table 4 shows the values of forage supply (FA) and leaf supply (LBA) of forage sorghum, which showed no significant difference between planting patterns. It was observed an average FA of $9.87 \mathrm{~kg}$ of DM per $100 \mathrm{~kg}$ of $\mathrm{LW}$, which is a value lower than that recommended by Sollenberger and Burns (2001), which reported values ranging from 10 to $12 \mathrm{~kg}$ of DM per $100 \mathrm{~kg}$ of LW as an ideal offer for tropical forage species. However, it should be considered that in the present study the animals were supplemented at the level of $1 \%$ of liveweight. As mentioned by Osmari et al. (2011), offers between 7 and $9.5 \mathrm{~kg}$ of DM per $100 \mathrm{~kg}$ of LW in forage sorghum pastures allow good forage responses, in addition to good levels of animal performance. The planting pattern S22D12 presented FA of $13.54 \mathrm{~kg}$ of DM per $100 \mathrm{~kg}$ of LW, which is higher than the recommended by those authors, but with no significant difference from the other assessed patterns.

Table 4. Productive parameters of the forage sorghum pasture implanted under different planting patterns.

\begin{tabular}{lrrrrrrrr}
\hline \multicolumn{1}{c}{ Interrow spacing, cm } & \multicolumn{2}{c}{44} & \multicolumn{2}{c}{22} & \multirow{2}{*}{ SEM $^{2}$} & \multicolumn{3}{c}{$\mathrm{P}<\mathrm{F}^{1}$} \\
\cline { 2 - 4 } \cline { 8 - 10 } Density, $\mathrm{kg} \mathrm{ha}^{-1}$ & 12 & 24 & 12 & 24 & & $\mathrm{~S}$ & $\mathrm{D}$ & $\mathrm{S} \times \mathrm{D}$ \\
\hline LBA & 3.49 & 3.52 & 4.57 & 3.31 & 1.04 & 0.600 & 0.569 & 0.458 \\
FA & 8.94 & 8.66 & 13.54 & 8.35 & 1.98 & 0.286 & 0.177 & 0.224 \\
MLB & 231.87 & 227.26 & 198.51 & 274.34 & 66.86 & 0.753 & 0.736 & 0.737 \\
MF & 1319.35 & 1062.38 & 1559.96 & 1174.75 & 234.73 & 0.774 & 0.098 & 0.797 \\
AR & 59.11 & 46.89 & 63.56 & 64.31 & 14.22 & 0.219 & 0.505 & 0.452 \\
SR & 1148.44 & 1235.30 & 1047.71 & 1257.84 & 151.88 & 0.803 & 0.357 & 0.696 \\
\hline
\end{tabular}

LBA = sorghum leaf supply ( $\mathrm{kg}$ of DM per $100 \mathrm{~kg}$ of LW); FA = forage supply ( $\mathrm{kg}$ of DM per $100 \mathrm{~kg}$ of LW); MLB = leaf mass of sorghum $\left(\mathrm{kg}\right.$ of DM ha $\left.{ }^{-1}\right) ; \mathrm{MF}=$ forage mass $\left(\mathrm{kg}\right.$ of $\left.\mathrm{DM} \mathrm{ha}{ }^{-1}\right) ; \mathrm{AR}=$ accumulation rate $\left(\mathrm{kg}\right.$ of DM ha $\left.{ }^{-1} \mathrm{day}^{-1}\right) ; \mathrm{SR}=$ stocking rate $\left(\mathrm{kg}\right.$ of $\left.\mathrm{LW} \mathrm{ha} \mathrm{H}^{-1}\right)$.

'Effect of S: spacing; D: density; S × D: interaction between spacing and density.

${ }^{2} \mathrm{SEM}$ : standard error of the mean. 
The average LBA between planting patterns was of $3.72 \mathrm{~kg}$ of DM per $100 \mathrm{~kg}$ of LW, indicating a LBA higher than the potential consumption of heifers with average age of 18 months because, according to the NRC (1996), it is estimated at $2.5 \%$ of the LW. When the analysis is performed as a function of the assessment periods (Table 5), it can be observed that in the period 3 the LBA and FA were lower $(\mathrm{P}<0.05)$ compared to the other assessment periods; the decrease was of $86.16 \%$ and $59.17 \%$ from the first to the third period for LBA and FA, respectively. The decrease in ADG observed in the period 3 may be related to the decrease in FA $(\mathrm{r}=0.43 ; \mathrm{P}=0.008)$ associated with the decrease in $\mathrm{CP}$ content $(\mathrm{r}=0.65 ; \mathrm{P}<0.0001)$. The decrease in FA was caused by reduced pasture growth rate, observed by the decrease in accumulation rate (AR) $(\mathrm{r}=0.81 ; \mathrm{P}<0.0001)$ over the assessment period, with a decrease from 75.84 and $79.11 \mathrm{~kg}$ of DM ha ${ }^{-1}$ day $^{-1}$ in the first and second periods, respectively, to $20.46 \mathrm{~kg}$ of $\mathrm{DM} \mathrm{ha}{ }^{-1}$ day $^{-1}$ in the third period, associated with the maintenance of the stocking rate $(\mathrm{SR})(\mathrm{r}=-0.56 ; \mathrm{P}=0.0003)$ observed during the experimental period, with average of $1,172.32 \mathrm{~kg}$ of LW ha ${ }^{-1}$ (Table 5), due to the evolution in body weight of the testing heifers.

Table 5. Productive parameters of the forage sorghum pasture implanted under different planting patterns for different assessment periods.

\begin{tabular}{|c|c|c|c|c|c|}
\hline & \multicolumn{3}{|c|}{ Period } & \multirow{2}{*}{$\mathrm{SEM}^{1}$} & \multirow{2}{*}{$\mathrm{P}<\mathrm{F}$} \\
\hline & 1 & 2 & 3 & & \\
\hline LBA & $7.30^{\mathrm{a}}$ & $2.86^{\mathrm{b}}$ & $1.01^{\mathrm{c}}$ & 0.44 & 0.0001 \\
\hline FA & $12.98^{\mathrm{a}}$ & $11.62^{\mathrm{a}}$ & $5.03^{b}$ & 1.39 & 0.002 \\
\hline MLB & $474.72^{\mathrm{a}}$ & $148.57 b$ & $75.70 \mathrm{c}$ & 24.39 & 0.0001 \\
\hline MF & $1312.72^{\mathrm{a}}$ & $1587.19^{a}$ & $936.66 b$ & 207.70 & 0.042 \\
\hline AR & $75.84^{\mathrm{a}}$ & $79.11^{\mathrm{a}}$ & $20.46 b$ & 5.85 & 0.0001 \\
\hline SR & 1035.04 & 1281.43 & 1200.49 & 94.18 & 0.201 \\
\hline
\end{tabular}

LBA = sorghum leaf supply ( $\mathrm{kg}$ of DM per $100 \mathrm{~kg}$ of LW); FA = forage supply ( $\mathrm{kg}$ of DM per $100 \mathrm{~kg}$ of LW); MLB = leaf mass of sorghum $\left(\mathrm{kg}\right.$ of DM ha $\left.{ }^{-1}\right) ; \mathrm{MF}=$ forage mass $\left(\mathrm{kg}\right.$ of $\left.\mathrm{DM} \mathrm{ha}{ }^{-1}\right) ; \mathrm{AR}=$ accumulation rate $\left(\mathrm{kg}\right.$ of $\left.\mathrm{DM} \mathrm{ha} \mathrm{hay}^{-1}\right)$; $\mathrm{SR}=$ stocking rate $\left(\mathrm{kg}\right.$ of $\left.\mathrm{LW} \mathrm{ha} \mathrm{h}^{-1}\right)$.

Means in the same row, followed by different letters, are statistically different from each other by the $\mathrm{t}$ test $(\mathrm{P}<0.05)$.

${ }^{1}$ SEM: standard error of the mean.

In the period 1 was observed a higher LBA, which represented $56.24 \%$ of the FA. This shows the rapid growth that the pasture of forage sorghum presented at the beginning of the vegetation period. In the periods 2 and 3, the LBA corresponded to $24.61 \%$ and $20.08 \%$ of the FA, reflecting a clear decrease in the forage sorghum growth as its physiological stage advanced, which can be observed in the structural composition expressed in terms of the experimental periods (Table 3 ). From the period 1 to the period 3 , the leaf participation decreased by $88.8 \%$ and the stem participation decreased by $61.14 \%$, which resulted in decreased leaf mass (MLB) participation in the forage mass (MF), which was of $36.16 \%$ in the first period and reached the value of $8.08 \%$ in the third period.

The MLB and MF were similar $(\mathrm{P}>0.05)$ between planting patterns, but there was a decrease in the MLB values in the order of $68 \%$ from the first to the second grazing period (from 474.72 to $148.57 \mathrm{~kg}$ of $\mathrm{DM} \mathrm{ha}^{-1}$, respectively) and $49 \%$ from the second to the third period (from 148.57 to $75.70 \mathrm{~kg}$ of $\mathrm{DM} \mathrm{ha}^{-1}$ day $^{-1}$, respectively) as the grazing period advanced. During the first and third grazing period, the MF values were similar, being obtained values of 1,312.72 and 1,587.19 $\mathrm{kg}$ of DM ha $\mathrm{Da}^{-1}$, respectively. However, in the first period, $36.16 \%$ of the MF was composed of leaf blades of forage sorghum; in the 
second period occurred a decrease of $9.36 \%$; and in the third period, this value decreased by $8.08 \%$ when compared to the first period.

The decreased participation of leaf blade of forage sorghum in the total forage mass reflects the preferential consumption of leaves by the animals when compared to other plant parts (FONSECA et al., 2013) due to the lower bromatological quality of the stems in relation to leaves (BENVENUTTI et al., 2008). As the cycle advances and the photoperiod decreases, the plants tend to flower differentiation, decreasing the leaf appearance rate, which is lower compared to the consumption of leaves, reflecting the decrease in mass and leaf supply. Roman et al. (2008) report similar behavior in millet pasture.

The accumulation rate (AR) of dry matter of the pasture did not differ significantly $(\mathrm{P}<0.05)$ between the planting patterns assessed, reaching an average value of $58.47 \mathrm{~kg}$ of $\mathrm{DM} \mathrm{ha}^{-1} \mathrm{day}^{-1}$, which is lower than those values reported by Pacheco et al. (2014) in millet pastures $\left(80.52 \mathrm{~kg}\right.$ of DM ha $\left.{ }^{-1}\right)$ and in sudan grass $\left(74.43 \mathrm{~kg}\right.$ of DM ha $\left.{ }^{-1}\right)$. The AR decreased as a function of the decrease in the photoperiod and beginning of floral differentiation of the forage sorghum as the pasture utilization cycle advanced (Table 5), going from an accumulation of 75.85 to $20.46 \mathrm{~kg}$ of $\mathrm{DM} \mathrm{ha}{ }^{-1}$ from the first to the third period, respectively. Roman et al. (2008) observed similar behavior in millet pasture, where there was a linear decrease in the forage daily accumulation rate as the grazing period advanced.

The SR did not differ between planting patterns and between assessment periods, with average of $1,172.32 \mathrm{~kg} \mathrm{LW} \mathrm{ha}^{-1}$. With the increase in heifer weight over the assessment periods, an increased SR was observed in the third grazing period, associated with a decreased AR and MF, resulting in a decreased FA. Values higher than those observed in this study were reported by Restle et al. (2002) in forage sorghum pastures $\left(1,389 \mathrm{~kg}\right.$ of $\left.\mathrm{LW} \mathrm{ha}{ }^{-1}\right)$ and by Pacheco et al. (2014) in millet $(1,741 \mathrm{~kg} \mathrm{LW}$ $\mathrm{ha}^{-1}$ ).

Table 6 presents the variables weight gain per area unit (WGA), total dry matter production (DMP) and canopy height as a function of the planting patterns studied. The canopy height did not differ $(\mathrm{P}>0.05)$ between the tested planting patterns, with an average value of $58.01 \mathrm{~cm}$. This probably did not limit the forage consumption by the animals since the canopy structure provided leaf blade allowance, on average, higher than the expected consumption of dry matter ( $2.5 \%$ of the $\mathrm{LW})$ during the experimental period. Fonseca et al. (2012), when establishing grazing management goals in forage sorghum in order to maximize the forage intake, defined as a parameter an average height of $50 \mathrm{~cm}$.

Table 6. Productive parameters of the forage sorghum pasture implanted with different planting patterns.

\begin{tabular}{lrrrrrrrr}
\hline \multicolumn{1}{c}{ Interrow spacing, cm } & \multicolumn{2}{c}{44} & \multicolumn{2}{c}{22} & \multirow{2}{*}{ SEM $^{2}$} & \multicolumn{3}{c}{${\mathrm{P}<\mathrm{F}^{1}}$} \\
\cline { 2 - 4 } \multicolumn{1}{c}{ Density, $\mathrm{kg} \mathrm{ha}^{-1}$} & \multicolumn{1}{c}{24} & \multicolumn{1}{c}{12} & \multicolumn{1}{c}{$\mathrm{S}$} & & \multicolumn{1}{c}{$\mathrm{D}$} & $\mathrm{S} \times \mathrm{D}$ \\
\hline WGA & 284.13 & 365.57 & 283.33 & 316.20 & 42.75 & 0.574 & 0.218 & 0.586 \\
Height & 60.23 & 60.32 & 58.64 & 52.84 & 6.37 & 0.485 & 0.659 & 0.648 \\
DMP & 5556.7 & 4563.77 & 5880.59 & 5790.06 & 1194.76 & 0.294 & 0.455 & 0.531 \\
\hline
\end{tabular}

WGA = weight gain per area unit $\left(\mathrm{kg} \mathrm{ha}^{-1}\right)$; Height $=$ canopy height $(\mathrm{cm})$; DMP $=$ dry matter production $\left(\mathrm{kg} \mathrm{ha}^{-1}\right)$.

${ }^{1}$ Effect of S: spacing; D: density; $\mathrm{S} \times \mathrm{D}$ : interaction between spacing and density.

${ }^{2} \mathrm{SEM}$ : standard error of the mean. 
The WGA was not influenced $(\mathrm{P}<0.05)$ by the planting patterns. The similarity observed for WGA is related to a similarity between ADG and SR observed between planting patterns, with average values of ADG of $312.31 \mathrm{~kg}$ of LW ha ${ }^{-1}$ and DMP of $5,447.78 \mathrm{~kg}$ of DM ha $\mathrm{D}^{-1}$ over 84 days of grazing. Restle et al. (2002) reported WGA values of 570.30 and $639.90 \mathrm{~kg}$ of LW ha ${ }^{-1}$ for forage sorghum and millet, which are higher than the values obtained in this study. However, these high values were obtained in a period of greater pasture utilization.

The DMP did not differ between the planting patterns tested, showing an average value of $5,447.78 \mathrm{~kg}$ of $\mathrm{DM} \mathrm{ha} \mathrm{h}^{-1}$ over 84 days of pasture utilization. Roman et al. (2008) report DMP values in millet of 7,077.6 $\mathrm{kg}$ of $\mathrm{DM} \mathrm{ha} \mathrm{h}^{-1}$ over 63 days of pasture utilization and application of $150 \mathrm{~kg} \mathrm{ha}^{-1}$ of nitrogen. Orth et al. (2012) obtained an average production of 6,550 and $6,000 \mathrm{~kg}$ of $\mathrm{DM} \mathrm{ha}{ }^{-1}$ for forage sorghum and millet, respectively, with the application of $135 \mathrm{~kg} \mathrm{ha}^{-1}$ of nitrogen in topdressing.

Table 7 presents the variables related to animal performance. There was no interaction $(\mathrm{P}>0.05)$ between planting patterns and assessment periods. The different interrow spacings and seed densities per hectare did not affect the animal performance variables, reflecting the equivalence observed in the variables related to the production parameters of the pasture.

Table 7. Heifer performance at finishing phase in forage sorghum pasture implanted under different planting patterns.

\begin{tabular}{|c|c|c|c|c|c|c|c|c|}
\hline \multirow{2}{*}{$\begin{array}{l}\text { Interrow spacing, } \mathrm{cm} \\
\text { Density, } \mathrm{kg} \mathrm{ha}^{-1}\end{array}$} & \multicolumn{2}{|c|}{44} & \multicolumn{2}{|c|}{22} & \multirow{2}{*}{$\mathrm{SEM}^{2}$} & \multicolumn{3}{|c|}{$\mathrm{P}<\mathrm{F}^{1}$} \\
\hline & 12 & 24 & 12 & 24 & & $\mathrm{~S}$ & $\mathrm{D}$ & $\mathrm{S} \times \mathrm{D}$ \\
\hline IW & 263.88 & 259.44 & 264.72 & 263.00 & 12.80 & 0.865 & 0.811 & 0.916 \\
\hline FW & 335.00 & 339.22 & 312.00 & 335.22 & 13.78 & 0.914 & 0.927 & 0.693 \\
\hline $\mathrm{ADG}$ & 0.847 & 0.949 & 0.920 & 0.847 & 0.06 & 0.874 & 0.683 & 0.125 \\
\hline IBCS & 2.87 & 2.86 & 2.90 & 2.90 & 0.07 & 0.589 & 0.983 & 0.938 \\
\hline FBCS & 3.67 & 3.75 & 3.76 & 3.77 & 0.06 & 0.393 & 0.493 & 0.607 \\
\hline GBCS & 0.80 & 0.89 & 0.86 & 0.87 & 0.08 & 0.827 & 0.514 & 0.611 \\
\hline SFT & 3.87 & 4.17 & 3.98 & 4.12 & 0.35 & 0.938 & 0.545 & 0.840 \\
\hline
\end{tabular}

$\mathrm{IW}=$ Initial weight $(\mathrm{kg}) ; \mathrm{FW}=$ final weight $(\mathrm{kg}) ; \mathrm{ADG}=$ average daily gain $\left(\mathrm{kg} \mathrm{day}^{-1}\right)$; IBCS = initial body condition score; $\mathrm{FBCS}$ = final body condition score; GBCS = gain in body condition score; SFT = subcutaneous fat thickness (mm).

${ }^{1}$ Effect of S: spacing; D: density; $\mathrm{S} \times \mathrm{D}$ : interaction between spacing and density.

${ }^{2} \mathrm{SEM}$ : standard error of the mean.

At the end of the experimental period, the final weight (FW) of heifers was on average of $330.36 \mathrm{~kg}$ of LW for planting patterns, with a subcutaneous fat thickness (SFT) of $4.04 \mathrm{~mm}$. These values are within the standards required by the meatpacking industry, which adopts a SFT from 3 to $6 \mathrm{~mm}$ (VAZ et al., 2010) and $180 \mathrm{~kg}$ of hot carcass weight. During the finishing phase are usually obtained lower slaughter weight values for young heifers when compared to steers of the same age. According to Berg and Butterfield (1976), the lowest weight of heifers is because they begin to deposit fat earlier, decreasing the growth rate. This behavior can be observed in this study when confronting the values of FW and SFT.

The ADG during the experimental period was of $0.891 \mathrm{~kg}$ day $^{-1}$, which is sufficient to ensure the finishing of heifers with adequate fattening and slaughter weight. The similar performance observed between treatments can be attributed to the adequate leaf supply, which allow the animal behavior of natural selection of food with better quality, and supplementation provided. Montagner et al. (2008) studied the heifer rearing in millet pasture and obtained, on average, $0.777 \mathrm{~kg}_{\text {day }^{-1}}$ 
for ADG in heifers. Restle et al. (2002) assessed the rearing of males in different tropical grasses and reported an ADG in the order of $1.121 \mathrm{~kg}^{\mathrm{day}}{ }^{-1}$ in forage sorghum pasture and $1.188 \mathrm{~kg} \mathrm{day}^{-1}$ in millet pasture.

The smaller values of ADG were found at the end of the pasture utilization $\left(0.650 \mathrm{~kg} \mathrm{day}^{-1}\right)$ when compared to the first and second periods $(0.918$ and $1.117 \mathrm{~kg} \mathrm{day}^{-1}$, respectively) (Table 8). The decrease in $\mathrm{ADG}$, observed in the last assessment period, can be attributed to the decreased MF ( $r=0.45$;
$\mathrm{P}=0.005)$, which is related to the decrease in $\mathrm{AR}$ $(\mathrm{r}=0.57 ; \mathrm{P}=0.0003)$. With advancing the pasture cycle occurs a change in the canopy structure (Table 3), not allowing an adequate supply of nutrients for maintaining the performances as those obtained in the first and second periods of assessment. According to Fonseca et al. (2012), the decrease in the availability of leaves reflects in decreased forage consumption rate. In this sense, Benvenutti et al. (2008) observed a decrease in the forage consumption with an increase in the proportion of stem.

Table 8. Heifer performance at finishing phase in forage sorghum pasture implanted under different planting patterns for different assessment periods.

\begin{tabular}{lcccccc}
\hline & \multicolumn{4}{c}{ Period } & \multirow{2}{*}{ SEM $^{1}$} & \multirow{2}{*}{$\mathrm{P}<\mathrm{F}$} \\
\cline { 2 - 3 } & 1 & 2 & 3 & & 0.04 & $<0.0001$ \\
ADG & $0.918^{\mathrm{b}}$ & $1.117^{\mathrm{a}}$ & $0.659^{\mathrm{c}}$ & & 0.04 & 0.0003 \\
\hline WGA & $103.39^{\mathrm{b}}$ & $141.18^{\mathrm{a}}$ & $67.73^{\mathrm{c}}$ & & 9.91 & \\
\hline
\end{tabular}

$\mathrm{ADG}=$ average daily gain $\left(\mathrm{kg} \mathrm{day}^{-1}\right)$; WGA $=$ weight gain per area unit $\left(\mathrm{kg} \mathrm{ha}^{-1}\right)$.

Means in the same row, followed by different letters, are statistically different from each other by the $t$ test $(\mathrm{P}<0.05)$.

${ }^{1} \mathrm{SEM}$ : standard error of the mean.

The final body condition score (FBCS) and the gain in body condition score (GBCS) were not influenced by planting patterns. The average BCS observed between planting patterns was of 3.74 , indicating that the animals were already well fattened, which is supported by the SFT verified at the end of the experimental period. The FW of $330.36 \mathrm{~kg}$ of LW reached by the animals, combined with the BCS, indicates that the heifers had $73 \%$ of the adult weight of a bovine female $(450 \mathrm{~kg})$ at the end of the pasture utilization, and can be considered adequate so that the heifers present regular estrous for the next breeding season (VAZ et al., 2012) if the pasture had been used for rearing females.

The WGA as a function of the periods (Table 8) followed the same trend of the ADG due to the similarity of SR during the assessment periods, which can be observed by the positive correlation between the variables $(r=0.66 ; \mathrm{P}<0.0001)$. The highest value of WGA was found in the second grazing period, with value of $141.18 \mathrm{~kg} \mathrm{ha}^{-1}$, followed by the first period with $103.39 \mathrm{~kg} \mathrm{ha}^{-1}$. In the third period, there was a decrease of $44.6 \%$ (122.29 vs $67.73 \mathrm{~kg} \mathrm{ha}^{-1}$ ) in WGA when compared to the first 56 days of pasture utilization. Pacheco et al. (2014) observed similar behavior in millet and Sudan grass pastures, who found a decreased WGA in the order of $47 \%$ at the end of pasture utilization period.

Table 9 shows the variables related to body development of heifers during the experimental period. No significant differences were observed $(\mathrm{P}<0.05)$ in the variables as a function of planting patterns, interrow spacings and seed density used. 
Table 9. Body performance of heifer at finishing phase in forage sorghum pasture implanted under different planting patterns.

\begin{tabular}{|c|c|c|c|c|c|c|c|c|}
\hline \multirow{2}{*}{$\begin{array}{l}\text { Interrow spacing, cm } \\
\text { Density, } \mathrm{kg} \mathrm{ha}^{-1}\end{array}$} & \multicolumn{2}{|c|}{44} & \multicolumn{2}{|c|}{22} & \multirow{2}{*}{$\mathrm{SEM}^{2}$} & \multicolumn{3}{|c|}{$\mathrm{P}<\mathrm{F}^{1}$} \\
\hline & 12 & 24 & 12 & 24 & & $\mathrm{~S}$ & $\mathrm{D}$ & $\mathrm{S} \times \mathrm{D}$ \\
\hline $\mathrm{Li}$ & 123.22 & 125.56 & 123.78 & 122.67 & 2.27 & 0.611 & 0.789 & 0.454 \\
\hline Lf & 133.44 & 133.28 & 131.22 & 130.11 & 2.15 & 0.218 & 0.768 & 0.827 \\
\hline HGi & 151.89 & 148.89 & 152.00 & 150.44 & 2.23 & 0.711 & 0.314 & 0.748 \\
\hline HGf & 164.94 & 163.28 & 164.06 & 164.72 & 2.42 & 0.909 & 0.838 & 0.633 \\
\hline HHi & 123.33 & 123.22 & 121.94 & 121.89 & 1.75 & 0.442 & 0.962 & 0.987 \\
\hline HHf & 125.98 & 128.61 & 126.44 & 125.98 & 1.60 & 0.504 & 0.504 & 0.340 \\
\hline W/Hi & 2.36 & 2.34 & 2.35 & 2.37 & 0.11 & 0.931 & 0.988 & 0.898 \\
\hline W/Hf & 2.73 & 2.60 & 2.66 & 2.69 & 0.11 & 0.885 & 0.651 & 0.495 \\
\hline
\end{tabular}

$\mathrm{Li}=$ initial length $(\mathrm{cm}) ; \mathrm{Lf}=$ final length $(\mathrm{cm}) ; \mathrm{HGi}=$ initial heart girth $(\mathrm{cm}) ; \mathrm{HGf}=$ final heart girth $(\mathrm{cm}) ; \mathrm{HHi}=$ initial hip height $(\mathrm{cm}) ; \mathrm{HHf}=$ final hip height $(\mathrm{cm}) ; \mathrm{W} / \mathrm{Hi}=$ initial weight to height ratio; W/Hf $=$ final weight to height ratio.

${ }^{1}$ Effect of S: spacing; D: density; $\mathrm{S} \times \mathrm{D}$ : interaction between spacing and density.

${ }^{2} \mathrm{SEM}$ : standard error of the mean.

The FW was positively correlated with the initial length (Li) $(\mathrm{r}=0.77 ; \mathrm{P}<0.0001)$, initial heart girth (HGi) $(\mathrm{r}=0.80 ; \mathrm{P}<0.0001)$ and initial hip height (HHi) $(\mathrm{r}=0.74 ; \mathrm{P}<0.0001)$, which demonstrate that the animals that presented a more developed body structure at the beginning of the experimental period required less time to complete the muscular development and start the adipose tissue deposition, in view of the similarity of animal weight gain.

The final heart girth (HGf) was positively correlated with FW $(\mathrm{r}=0.88 ; \mathrm{P}<0.0001)$. Pizzuti et al. (2012) report a correlation of 0.73 between the same variables. According to these authors, the positive correlation between these variables indicates that in structural conditions of the pasture that not limit consumption, animals with higher heart girth present increased dry matter intake capacity and better performance. The final hip height (HHf) was not affected by the different planting patterns used. The weight to height ratio $(\mathrm{W} / \mathrm{H})$ was similar between treatments, showing that the body growth was similar between planting patterns, and presented average value of $2.67 \mathrm{~kg} \mathrm{~cm}^{-1}$.

\section{Conclusions}

The alterations in planting patterns of forage sorghum pasture do not alter the production parameters of the pasture and animal performance. With advancing, the pasture cycle utilization occurs a decrease in the accumulation rate, leaf blades participation of forage sorghum in the forage mass and forage supply, and bromatological quality of forage, reflecting in decreasing animal performance.

\section{References}

ALVARES, C. A.; STAPE, J. L.; SENTELHAS, P. C.; DE MORAES, G.; LEONARDO, J.; SPAROVEK, G. Köppen's climate classification map for Brazil. Meteorologische Zeitschrift, Stuttgart, v. 22, n. 6, p. 711728, 2013.

ALVES, M. B.; ROCHA, M. G.; PÖTTER, L.; STIVANIN, S. C. B.; HAMPEL, V. S.; FONSECA NETO, A. M.; SICHONANY, M. J. O.; MOTERLE, P. H. Uso de suplementos para acasalamento de bezerras Angus aos 14 meses de idade. Arquivo Brasileiro de Medicina Veterinária e Zootecnia, Belo Horizonte, v. 68, n. 3, p. 755-760, 2016.

ARGENTA, G.; SILVA, P. D.; BORTOLINI, C. G.; FORSTHOFER, E. L.; MANJABOSCO, E. A.; BEHEREGARAY NETO, V. Resposta de híbridos simples de milho à redução do espaçamento entre linhas. Pesquisa Agropecuária Brasileira, Brasília, v. 36, n. 1, p. 71-78, 2001. 
ASSOCIATION OF OFFICIAL ANALYTICAL CHEMISTRY - AOAC. Official methods of analysis. $16^{\text {th }}$ ed. Arlington: AOAC International, 1995. $1025 \mathrm{p}$.

BENVENUTTI, M. A.; GORDON, I. J.; POPPI, D. P. The effects of stem density of tropical swards and age of grazing cattle on their foraging behaviour. Grass Forage Science, Oxford, v. 63, n. 1, p. 1-8, 2008.

BERG, R. T.; BUTTERFIELD, R. M. New concepts of cattle growth. Sydney: Sydney University Press, University of Sydney, 1976. 255 p.

BRACHTVOGEL, E. L.; PEREIRA, F. D. S.; CRUZ, S. C. S.; BICUDO, S. J. Densidades populacionais de milho em arranjos espaciais convencional e equidistante entre plantas. Ciência Rural, Santa Maria, v. 39, n. 8, p. 23342339, 2009.

BULLOCK, D. G.; NIELSEN, R. L.; NYQUIST, W. E. A growth analysis comparison of corn grown in conventional and equidistant plant spacing. Crop Science, Madison, v. 28, n. 2, p. 254-258, 1988.

CAMPBELL, A. G. Grazed pastures parameters; I. Pasture dry matter production and availability in a stocking rate and grazing management experiment with dairy cows. Journal Agriculture Science, Cambridge, v. 67, n. 2, p. 211-216, 1966.

CARNEIRO, J. C.; NOVAES, L. P.; RODRIGUES, J. A. S.; LOPES, F. C. F.; LIMA, C. B.; RODRIGUEZ, N. M.; LÉDO, F. J. S. Avaliação agronômica de híbridos de sorgo (Sorghum bicolor x Sorghum sudanense) sob regime de corte. In: CONGRESSO NACIONAL DE MILHO E SORGO, SIMPÓSIO BRASILEIRO SOBRE A LAGARTA-DO-CARTUCHO, 1; 25., 2004, Cuiabá. Anais... Cuiabá: CNMS, Embrapa Milho e Sorgo, 2004. CD-ROOM.

CHIElle, Z. G.; TOMAZZI, D. J.; LOSSO, A. C.; RAUPP, A. A. A.; PERES, P. S.; PORCIUNCULA, J. A. F. Ensaio Sul-Rio-Grandense de sorgo para corte ou pastejo 2000/2001, resultados da rede estadual. In: REUNIÃO TÉCNICA ANUAL DO MILHO, REUNIÃO TÉCNICA ANUAL DO SORGO, 29; 46., 2001, Porto Alegre. Anais... Porto Alegre: EMATER/RS, 2001. CDROOM.

DEVINCENZI, T.; NABINGER, C.; CARDOSO, F. F.; NALÉRIO, E. S.; CARASSAI, I. J.; FEDRIGO, J. K.; TAROUCO, J. U.; CARDOSO, L. L. Carcass characteristics and meat quality of Aberdeen Angus steers finished on different pastures. Revista Brasileira de Zootecnia, Viçosa, MG, v. 41, n. 4, p. 1051-1059, 2012.

EUCLIDES, V. P. B.; MACEDO, M. C. M.; OLIVEIRA, M. P. Avaliação de diferentes métodos de amostragem sob pastejo. Revista Brasileira de Zootecnia, Viçosa, MG, v. 21, n. 4, p. 691-702, 1992.

FONSECA, L.; CARVALHO, P. C. F.; MEZZALIRA, J. C.; BREMM, C.; GALLI, J. R.; GREGORINI, P. Effect of sward surface height and level of herbage depletion on bite features of cattle grazing Sorghum bicolor swards. Journal of Animal Science, Champaign, v. 91, n. 9, p. 4357-4365, 2013.

FONSECA, L.; MEZZALIRA, J. C.; BREMM, C.; FILHO, R. S. A.; GONDA, H. L.; CARVALHO, P. C. F. Management targets for maximizing the short-term herbage intake rate of cattle grazing in Sorghum bicolor. Livestock Science, New York, v. 145, n. 1, p. 205-211, 2012.

GONTIJO NETO, M. M.; ALVARENGA, R. C.; PEREIRA FILHO, I. A.; CRUZ, J. C.; RODRIGUES, J. A. S. Recomendações de densidades de plantio e taxas de semeaduras de culturas anuais e forrageiras em plantio consorciado. Sete Lagoas: Embrapa Milho e Sorgo, 2006. 6 p. (Comunicado técnico, 137). Disponível em: $<$ http:// www.cnpms.embrapa.br/publicacoes/publica/2006/ comunicado/Com_137.pdf>. Acesso em: 10 out. 2015.

INSTITUTO NACIONAL DE METEOROLOGIA INMET. BDMEP - Banco de dados meteorológicos para ensino e pesquisa. Brasília, 2015. Disponível em: $<$ http:// www.inmet.gov.br/portal/index.php?r= bdmep/bdmep $>$. Acesso em: 10 maio 2015.

KLINGMAN, D. L.; MILES, S. R.; MOTT, G. O. The cage method for determining consumption and yield of pasture herbage. Journal of the American Society of Agronomy, Madison, v. 35, n. 9, p. 739-746, 1943.

LOWMAN, B. G.; SCOTT, N.; SMERVILLE, S. Condition scoring beef cattle. Edinburgh: East of Scotland College of Agriculture, 1973. 8 p.

MAGALHÃES, M. D. A.; MARTUSCELlO, J. A.; FONSECA, D. M. da; OLIVEIRA, I. M. de; FREITAS, F. P. de; FARIA, D. J. G.; RIBEIRO JÚNIOR, J. I. Influência da irrigação, da densidade de plantio e da adubação nitrogenada nas características morfogênicas, estruturais e de produção do capim-tanzânia. Revista Brasileira de Zootecnia, Viçosa, MG, v. 40, n. 11, p. 2308-2317, 2011.

MARSALIS, M. A.; ANGADI, S. V.; CONTRERASGOVEA, F. E. Dry matter yield and nutritive value of corn, forage sorghum, and BMR forage sorghum at different plant populations and nitrogen rates. Field Crops Research, Amsterdam, v. 116, n. 1, p. 52-57, 2010.

MONTAGNER, D. B.; ROCHA, M. G.; SANTOS, D. T.; GENRO, T. C. M.; QUADROS, F. L. F.; ROMAN, J.; BREMM, C. Manejo da pastagem de milheto para recria 
novilhas de corte. Ciência Rural, Santa Maria, v. 38, n. 8, p. 2293-2299, 2008.

MOOT, G. O.; LUCAS, H. L. The design conduct and interpretation of grazing trials on cultivated and improved pastures. In: PROCEEDINGS OF THE INTERNATIONAL GRASSLAND CONGRESS, 1952, Pensylvania. Proceedings... Pensylvania: State College, 1952. p. 1380-1395.

NATIONAL RESEARCH COUNCIL - NRC. Nutrients requirements of beef cattle. $7^{\text {th }}$ ed. Washington: National Academy Press, 1996. 244 p.

NEUMANN, M.; RESTLE, J.; ALVES FILHO, D. C.; MACCARI, M.; PELLEGRINI, L. G.; SOUZA, A. N. M.; PEIXOTO, L. A. O. Qualidade de forragem e desempenho animal em pastagem de sorgo (Sorghum bicolor, L.), fertilizada com dois tipos de adubo, sob pastejo contínuo. Revista Brasileira de Agrociência, Pelotas, v. 11, n. 2, p. 221-226, 2005.

NEUMANN, M.; RESTLE, J.; NÖRNBERG, J. L.; OLIBONI, R.; PELLEGRINI, L. G.; FARIA, M. V.; OLIVEIRA, M. R. Efeito associativo do espaçamento entre linhas de plantio, densidade de plantas e idade sobre o desempenho vegetativo e qualitativo do sorgo forrageiro. Revista Brasileira de Milho e Sorgo, Sete Lagoas, v. 7, n. 2, p. 165-181, 2008.

ORTH, R.; FONTANELI, R. S.; FONTANELI, S.; SACCARDO, E. Produção de forragem de gramíneas anuais semeadas no verão. Ciência Rural, Santa Maria, v. 42, n. 9, p. 1534-1540, 2012.

OSMARI, M. P.; ARGENTA, F. M.; PAULA, P. C.; ALVES FILHO, D. C.; BRONDANI, I. L. Produção de bovinos de corte em pastagem de estação quente no sul do Brasil - Uma revisão. Pubvet, Londrina, v. 5, n. 22, p. 1-21, 2011.

PACHECO, R. F.; ALVES FILHO, D. C.; BRONDANI, I. L.; NORNBERG, J. L.; PIZZUTI, L. A. D.; CAllegaro, Á. M. Características produtivas de pastagens de milheto ou capim sudão submetidas ao pastejo contínuo de vacas para abate. Ciência Animal Brasileira, Goiânia, v. 15, n. 3, p. 266-276, 2014.

PIZZUTI, L. A. D.; ALVES FILHO, D. C.; BRONDANI, I. L.; RESTLE, J.; FREITAS, L. D. S.; ARGENTA, F. M.; CARDOSO, G. D. S. Development and reproductive performance of beef heifers supplemented with brown rice meal and/or protected fat on temperate grasslands. Revista Brasileira de Zootecnia, Viçosa, MG, v. 41, n. 10, p. 2263-2271, 2012.
RESTLE, J.; ROSO, C.; AITA, V.; NORNBERG, J. L.; BRONDANI, I. L.; CERDÓTES, L.; CARRILO, C. O. Produção animal em pastagem com gramíneas de estação quente. Revista Brasileira de Zootecnia, Viçosa, MG, v. 31, n. 3, p. 1491-1500, 2002.

ROMAN, J.; ROCHA, M. D.; GENRO, T. C. M.; SANTOS, D. D.; FREITAS, F. D.; MONTAGNER, D. B. Características produtivas e estruturais do milheto e sua relação com o ganho de peso de bezerras sob suplementação alimentar. Revista Brasileira de Zootecnia, Viçosa, MG, v. 37, n. 2, p. 205-211, 2008.

SOLLENBERG, L. E.; MOORE, J. E.; ALLEN, V. G.; PEDREIRA, C. G. S. Reporting forage allowance in grazing experiments. Crop Science Society of America, Madison, v. 45, n. 3, p. 896-900, 2005.

SOLLENBERGER, L. E.; BURNS, J. C. Canopy characteristics, ingestive behavior and herbage intake in cultivated tropical grasslands. In: INTERNATIONAL GRASSLAND CONGRESS, 19., 2001, Piracicaba. Proceeding... Piracicaba: Fundação de Estudos Agrários Luiz de Queiroz, 2001. p. 321-327.

STRECK, E. V.; KÄMPF, N.; DALMOLIN, R. S. D.; KLAMT, E.; NASCIMENTO, P. D.; SCHNEIDER, P.; PINTO, L. F. S. Solos do Rio Grande do Sul. Porto Alegre: UFRGS, Departamento de Solos, Faculdade de Agronomia, 2008. 222 p.

VAN SOEST, P. J.; ROBERTSON, J. B.; LEWIS, B. A. Methods for dietary fiber, neutral detergent fiber, and nonstarch polyssacarides in relation to animal nutrition. Journal of Dairy Science, Madison, v. 74, n. 10, p. 35833597, 1991.

VAZ, F. N.; RESTLE, J.; ARBOITE, M. Z.; PASCOAL, L. L.; ALVES FILHO, D. C.; PACHECO, R. F. Características de carcaça e da carne de novilhos e novilhas superjovens, terminados com suplementação em pastagem cultivada. Ciência Animal Brasileira, Goiânia, v. 11, n. 1, p. 42-52, 2010.

VAZ, R. Z.; RESTLE, J.; PACHECO, P. S.; VAZ, F. N.; PASCOAL, L. L.; VAZ, M. B. Ganho de peso pré e pós-desmame no desempenho reprodutivo de novilhas de corte aos quatorze meses de idade. Ciência Animal Brasileira, Goiânia, v. 13, n. 3, p. 272-281, 2012.

WILM, H. G.; COSTEllo, D. F.; KLIPPLE, G. E. Estimating forage yield by the double sampling methods. Journal of American Society of Agronomy, Madison, v. 36, p. 194-203, 1944. 